\title{
Preoperative Patient Evaluation
}

Editors

ZDRAVKA ZAFIROVA

RICHARD D. URMAN

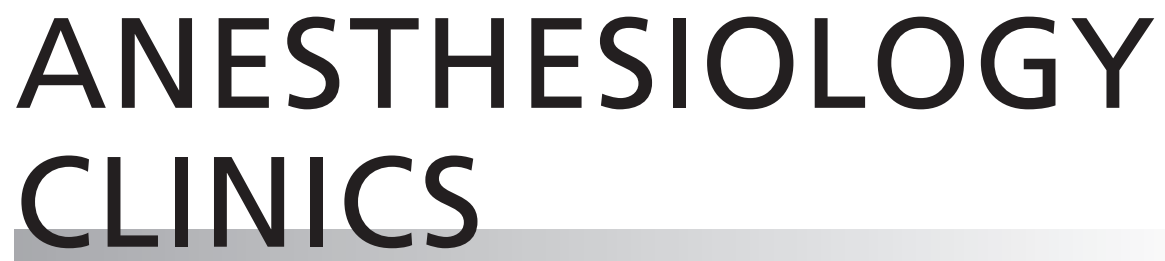

www.anesthesiology.theclinics.com

Consulting Editor

LEE A. FLEISHER

December 2018 • Volume 36 • Number 4 